\title{
The Ir indicator and its modification Im in patients operated on for infective endocarditis - usefulness in operative risk prognosis and postoperative therapy assessment
}

\author{
Wskaźnik Ir i jego modyfikacja Im u pacjentów operowanych z powodu \\ infekcyjnego zapalenia wsierdzia - przydatność w prognozowaniu ryzyka \\ operacji i ocenie skuteczności leczenia pooperacyjnego
}

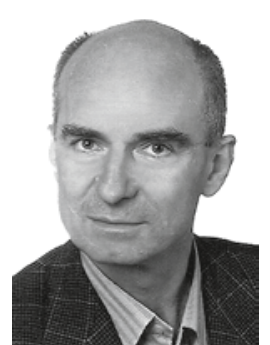

\author{
Stanisław Ostrowski ${ }^{1}$, Anna Marcinkiewicz ${ }^{2}$, Tomasz Skowroński ${ }^{1}$, Radosław Zwoliński ${ }^{1}$, Ryszard Jaszewski ${ }^{1}$ \\ ${ }^{1}$ Department of Cardiac Surgery, Chair of Cardiology and Cardiac Surgery, Medical University of Lodz, Poland \\ ${ }^{2}$ medical student of the $6^{\text {th }}$ year, Medical University of Lodz, Poland
}

Kardiochirurgia i Torakochirurgia Polska 2012; 3: 299-304

\begin{abstract}
Introduction: Anemia is a part of the endocarditis clinical presentation. C-reactive protein is one of the widely available inflammatory markers, which contributes to the diagnostic and prognostic process of infective endocarditis (IE). Both mentioned parameters are connected by the newly proposed risk indicator Ir.

The aim of the study was to assess its usefulness in patients subjected to cardiac surgery due to IE. We also evaluated the clinical application of the modified risk indicator Im.

Material and methods: The study involved 29 patients operated on for IE in the Cardiosurgical Clinic in Lodz. All laboratory examinations (CRP, RBC, $\mathrm{Hb}$ ) and proper calculations were carried out: preoperatively, on the $3^{\text {rd }}, 7^{\text {th }}, 12^{\text {th }}$ and $21^{\text {st }}$ postoperative day. Patients were divided into 2 groups: without $(A)$ or with (B) complications. The end points of prognostic significance were: decease, respiratory or circulatory failure over $72 \mathrm{~h}$, the time of hospitalization and stay in the intensive care unit (ICU).

Results: Postoperative complications were found in 17 (58.62\%) patients. A statistically significant increase of Ir and Im was observed on the $3^{\text {rd }}$ postoperative day (the highest values for the non-complicated group). The peak increase was noted on the $7^{\text {th }}$ day in the group with complications. The risk indicators began to decrease earlier in group $A$. The blood parameters decreased significantly on the $3^{\text {rd }}$ day and started to elevate significantly from the $12^{\text {th }}$ day. The perioperative mortality reached $10.34 \%$ (3) of patients.
\end{abstract}

\section{Streszczenie}

Wstęp: Anemia jest jedną ze składowych infekcyjnego zapalenia wsierdzia. Białko C-reaktywne (C-reactive protein - CRP) należy do szeroko dostępnych markerów zapalnych, odgrywających rolę w rozpoznaniu i prognozowaniu u pacjentów z infekcyjnym zapaleniem wsierdzia (IZW). Oba parametry łączy nowy wskaźnik ryzyka - Ir.

Cel pracy: Ocena przydatności Ir u pacjentów operowanych z powodu IZW. Oceniono także kliniczną przydatność zmodyfikowanego wskaźnika ryzyka - Im.

Materiały i metody: Badaniem objęto 29 pacjentów operowanych w Klinice Kardiochirurgii w Łodzi z powodu IZW. Wszystkie badania laboratoryjne (RBC, Hb, CRP) oraz odpowiednie obliczenia (Ir i Im) wykonano przed operacją oraz w 3., 7., 12. i 21. dobie pooperacyjnej. Pacjenci zostali podzieleni na 2 grupy: A - bez powikłań, B - z powikłaniami. Za punkty końcowe o znaczeniu predykcyjnym przyjęto: zgon, niewydolność oddechową lub krążenie > 72 godz., czas hospitalizacji i pobytu na oddziale intensywnej terapii (OIT). Przeanalizowano wystąpienie powikłań w przebiegu pooperacyjnym. Uwzględniono ilość przetaczanych preparatów krwi i krwiopochodnych.

Wyniki: Powikłania pooperacyjne wystąpity u 17 pacjentów (58,62\%). W 3. dobie pooperacyjnej stwierdzono istotny statystycznie wzrost Ir i Im (szczyt dla grupy niepowikłanej). W grupie z powikłaniami najwyższy wzrost przypadł dopiero na 7. dobę. W grupie A oba wskaźniki zaczęły obniżać się już w 7. dobie. W grupie B istotny spadek nastąpit dopiero W 12. dobie. Odnotowano istotny spadek parametrów krwi - RBC i Hb w 3. dobie

Address for correspondence: Stanisław Ostrowski, MD, PhD, Department of Cardiac Surgery, Chair of Cardiology and Cardiac Surgery, Medical University of Lodz, Poland, Phone/Fax +48 4263315 58, E-mail: stanislaw.ostrowski@umed.lodz.pl 
Conclusions: The prognostic value for postoperative complications was proved for Ir and Im. Their superiority to CRP was found.

Key words: risk indicators, infective endocarditis, valvular prosthesis implantation.

\section{Introduction}

Infective endocarditis (IE) remains a disease of high mortality, reaching even 10-50\%, despite appropriate antibiotic therapy [1]. Anemia is one of the clinical signs of endocarditis. It is a consequence of a long-lasting disease process and bacterial infection. The release of cytokines (mainly IL-6) is a response to the existing inflammatory process and it exerts a double effect. The cytokines stimulate synthesis of the acute phase proteins, including hepcidin, which despite its antimicrobial properties, is the main hormone regulating iron metabolism [2]. Furthermore, cytokines directly inhibit the medullary erythropoiesis. Inflammatory markers, including widely available C-reactive protein (CRP), are popular tools for monitoring patients with IE. They have also become indispensable for fast and proper diagnosis $[3,4]$, which plays a key role in complicated cases or those with a dramatic course [5].

The new risk indicator Ir, developed by B. Kraśnicka-Sokół et al. [6], joins the two above mentioned parameters. Diagnostic as well as prognostic value is assigned to it. Using this indicator the researchers have revealed a high-risk patient group, which should be qualified for earlier surgical intervention. Among patients involved in the mentioned study almost half underwent surgical treatment.

As a purpose of the study we decided to verify the risk indicator Ir among patients subjected to cardiac surgery due to valvular defects caused by endocardial infection. We have also modified the proposed Ir formula by replacing hemoglobin $(\mathrm{Hb})$ by the red blood cell count (RBC). We evaluated the obtained modified indicator $(\mathrm{Im})$ in clinical practice and tried to establish the threshold value for this parameter. Eventually we compared both of the indicators.

\section{Material and methods}

This study was retroprospective. In the study there were involved 29 patients admitted to the Cardiac Surgery Clinic of the Medical University of Lodz. For the group of 20 patients operated on subsequently in the clinic, the analysis and calculations were conducted retrospectively. Then 9 patients, admitted and operated on for IE, were enrolled in the study. Diagnosis of infective endocarditis was based on Duke's criteria [7]. The average time from the first symptoms to the final diagnosis was 24-30 days. The assessed group consisted of 16 men and 13 women. The average age was $52.14 \pm 15.11$. The average ejection fraction was $57.77 \%$. i istotny wzrost od 12. doby. W okresie okołooperacyjnym przetoczono 1 pacjentowi średnio 2,7 j. koncentratu krwinek czerwonych i 1,17 j. świeżo mrożonego osocza. Śmiertelność pooperacyjna wyniosła 10,34\% (zmarło 3 pacjentów).

Wnioski: Wykazano prognostyczną wartość Ir i Im co do pooperacyjnych powikłań oraz stwierdzono wyższość obu parametrów nad CRP.

Słowa kluczowe: wskaźniki ryzyka, infekcyjne zapalenie wsierdzia, implantacja sztucznej zastawki.

Fourteen (14, 48.3\%) patients were qualified as functional NYHA class III. In 8 (27.6\%) patients heart failure in NYHA class IV was diagnosed. In the perioperative period a standard for IE antibiotic therapy, according to the cultures and antibiograms, was administered to the patients. Patients' characteristics are presented in Table I.

In the study population there were $11(38 \%)$ artificial mitral valves (MVR) implanted. In 12 (41.38\%) cases an aortic valve replacement (AVR) was carried out (bioprostheses). In $1(3.45 \%)$ case mitral annuloplasty was performed and in the others complex procedures were conducted. All procedures included 3 redo surgeries. Heart protection was obtained with a cold crystalloid cardioplegic solution given antegrade (average $1519 \mathrm{ml}$ ). The average perfusion time was $104.56 \mathrm{~min}$ and the aortic cross-clamping time was 77.31 min. Although patients were given preoperative antibiotic therapy and the preoperative blood cultures were negative the valvular material collected intraoperatively was sent for microbial examination.

The analysis also included the amount of blood and blood-derived preparations (PRBC - packed red blood cells) transfused in the intra- and postoperative period. The mode of the surgery - emergent, urgent or scheduled - was also taken into account. Complications in the early postoperative period were also analyzed, inter alia respiratory or circulatory insufficiency lasting over $72 \mathrm{~h}$ (the necessity of mechanical ventilation or use of intra-aortic balloon counterpulsation - IABP), duration of stay in the intensive care unit (ICU) and complete hospitalization time.

Tab. I. Patients' preoperative characteristics including more significant comorbidities

\begin{tabular}{ll} 
Comorbidities & Number of patients \\
\hline history of stroke & 5 \\
\hline peripheral embolism & 3 \\
\hline $\begin{array}{l}\text { renal diseases } \\
\text { of myocardial infarction) }\end{array}$ & 3 \\
\hline cancer in the past history & 3 \\
\hline diabetes/IGT & 2 \\
\hline pulmonary disease & 4 \\
\hline history of sepsis & 5 \\
\hline history of steroids use & 2 \\
\hline
\end{tabular}


For each patient the value of the new risk indicator Ir was calculated, according to the formula proposed by B. Kraśnicka-Sokół et al. [6]:

$$
I r=\frac{C R P\left[\frac{m g}{l}\right]}{H g\left[\frac{g}{d l}\right]-\beta} \times 10 \quad, \text { where } \beta=6 \mathrm{~g} / \mathrm{dl} \text {. }
$$

Then the modified indicator was calculated, as shown below:

$$
I m=\frac{C R P\left[\frac{m g}{l}\right]}{R B C\left[\frac{m l n}{\mu l}\right]-\alpha} \times 10^{12}
$$

('multiplier $10^{12}$ is a result of units harmonization) $\operatorname{Ir}[\mathrm{mg}]$, where $\alpha=2.5 \mathrm{mln} / \mu \mathrm{l}$.

$2.5 \mathrm{mln} / \mu \mathrm{l}$ was accepted as the RBC threshold for which mortality risk is high (on the basis of the MHC formula, where the average hemoglobin value $25 \mathrm{pg}$ and the hemoglobin concentration $6 \mathrm{~g} / \mathrm{dl}$ were posited), which approximately reflects the content of hemoglobin $-6 \mathrm{~g} / \mathrm{dl}$.

All collected data (CRP, RBC and $\mathrm{Hb}$ ) and appropriate calculations (Ir and Im) were performed at consecutive check points: preoperatively, and on the $3^{\text {rd }}, 7^{\text {th }}, 12^{\text {th }}$ and $21^{\text {st }}$ postoperative day.

Patients were divided into 2 groups: A, without complications (12); and B, any complication during hospitalization (17).

The obtained data were statistically analyzed. The program SPSS version 9.0 was used. For all collected data mean values with standard deviations and median values were determined. Shapiro-Wilk's test was used for evaluation of the accordance with normal distribution. For comparison of the quantitative values with normal distribution Student's t-test was used. The nonparametric values were compared with $\chi^{2}$ test. Correlation of both risk indicators (Ir vs. Im) was evaluated with Spearman's correlation test. The dependency between $\mathrm{CRP}, \mathrm{RBC}$ and $\mathrm{Hb}$ at consecutive control points was studied. The value $p<0.05$ was considered as statistically significant.

\section{Results}

Comparison of the preoperative RBC with the value from the $3^{\text {rd }}$ postoperative day revealed a statistically significant (SS) decrease $(p=0.00011)$. Analogical dependency was found for $\mathrm{Hb}$ (SS, $p=0.0005$ ). Erythrocytes and hemoglobin started to increase from the $12^{\text {th }}$ postoperative day (SS, $p=$ 0.004 and $p=0.01$ ). There were no statistically significant differences in morphological parameters ( $\mathrm{RBC}$ and $\mathrm{Hb}$ ) between groups $\mathrm{A}$ (without complications) and B (with complications) (comparison of the average values of RBC and $\mathrm{Hb}$ in both groups for each control point, $p>0.05$ ) (Tables II, III).

In the perioperative period the average 2.7 PRBC and 1.17 units of FFP (fresh frozen plasma) were transfused to each patient. In the early postoperative period coagulation disorders were diagnosed in 2 patients. In 1 patient massive coagulation disturbances required 9 units of cryoprecipitate and 9 units of platelet concentrates (besides PRBC and FFP). Moreover, in 2 patients rethoracotomy was conducted because of the increased drainage. In the early postoperative period complications occurred in 17 (58.62\%) patients. Complications included cardiac arrhythmias, coagulation disorders, low output syndrome, cardiogenic shock (requiring catecholamines and/or IABP usage), perioperative stroke, respiratory insufficiency, acute renal failure, hydrothorax, sternal dehiscence, and pneumonia. In 6 patients complex complications were present.

The CRP peak occurred on the $3^{\text {rd }}$ postoperative day (SS, $p=0.001)$. After that time it started to decrease (SS, $7^{\text {th }}$ vs. $12^{\text {th }}$ day, $\left.p=0.006\right)$. This is compatible with our previous studies concerning inflammatory markers in patients with IE [8]. In the group with complications CRP levels were higher at each control point (SS, on the $7^{\text {th }}$ and $21^{\text {st }}$ postoperative day, $p=0.019$ and $p=0.026$ ). However, the variability of this parameter was identical in both groups (peak on the $3^{\text {rd }}$ day and gradual decrease from that control point).

In both groups we observed differences in alterations of Im and Ir. The maximal increase of both indicators occurred

Tab. II. Mean values of assessed morphological parameters, CRP and the prognostic indicators for the group without complications (A)

\begin{tabular}{lccccc} 
Parameter & Before surgery & $3^{\text {rd }}$ postoperative day & $7^{\text {th }}$ postoperative day & 12 $^{\text {th }}$ postoperative day & $2^{\text {st }}$ postoperative day \\
RBC & 3.84 & 3.30 & 3.48 & 3.85 & 4.27 \\
\hline $\mathrm{Hb}$ & 11.31 & 9.82 & 10.14 & 11.13 & 12.28 \\
\hline $\mathrm{CRP}$ & 22.41 & 91.73 & 59.60 & 32.47 & 76.30 \\
\hline $\mathrm{Ir}$ & 59.93 & 251.72 & 164.00 & 30.10 & 21.40 \\
\hline $\mathrm{Im}$ & 28.41 & 118.78 & 81.47 & 3.60 \\
\hline
\end{tabular}

Tab. III. Mean values of assessed morphological parameters, CRP and the prognostic indicators for the group with postoperative

\begin{tabular}{|c|c|c|c|c|c|}
\hline Parameter & Before surgery & $3^{\text {rd }}$ postoperative day & $7^{\text {th }}$ postoperative day & $12^{\text {th }}$ postoperative day & $21^{\text {st }}$ postoperative day \\
\hline RBC & 4.02 & 3.58 & 3.35 & 3.64 & 3.90 \\
\hline $\mathrm{Hb}$ & 11.77 & 10.53 & 9.80 & 10.47 & 10.90 \\
\hline CRP & 59.02 & 145.10 & 121.56 & 67.50 & 64.68 \\
\hline Ir & 136.71 & 363.28 & 426.78 & 187.58 & 191.36 \\
\hline Im & 67.63 & 213.91 & 303.50 & 95.85 & 74.44 \\
\hline
\end{tabular}
complications (B) 
on the $7^{\text {th }}$ postoperative day in the group with complications, while in the group without complications it occurred on the $3^{\text {rd }}$ postoperative day. But just on the $3^{\text {rd }}$ postoperative day we noted a statistically significant increase in both groups (SS, Ir $p=0.02$ for group $B$ and $p=0.013$ for group $\mathrm{A}, \operatorname{Im} p=0.015$ for group $\mathrm{B}$ and $p=0.016$ for group B). However, the increase of $\mathrm{Ir}>300$ and $\mathrm{Im}>200$ was associated with complications within the next days. On the $12^{\text {th }}$ day we noted a sudden decrease of these parameters in the group with complications (SS, $p=0.036$ for Ir and $p$ $=0.028$ for $1 \mathrm{~m}$ ), while in the group without complications both indicators began to decrease on the $7^{\text {th }}$ day (SS, for Ir $7^{\text {th }}$ vs. $12^{\text {th }}$ day $p=0.005$ and $12^{\text {th }}$ vs $21^{\text {st }}$ day $p=0.026$, for Im respectively, $p=0.012$ and $p=0.019$ ). Both indicators (Ir and Im) also had higher values for each control point in the group with complications. For the preoperative measurements Ir $>100$, which was compatible with the results of B. Kraśnicka-Sokół et al. [6] and Im > 60, which we established in our study, was helpful in prognosticating early complications. Statistical significance was confirmed only for the $21^{\text {st }}$ postoperative day (SS, $p=0.017$ ). In group $B$ we observed an Ir increase at the last control point of 3.78 (NS, $p=0.52$ ) (Figs. 1-4).

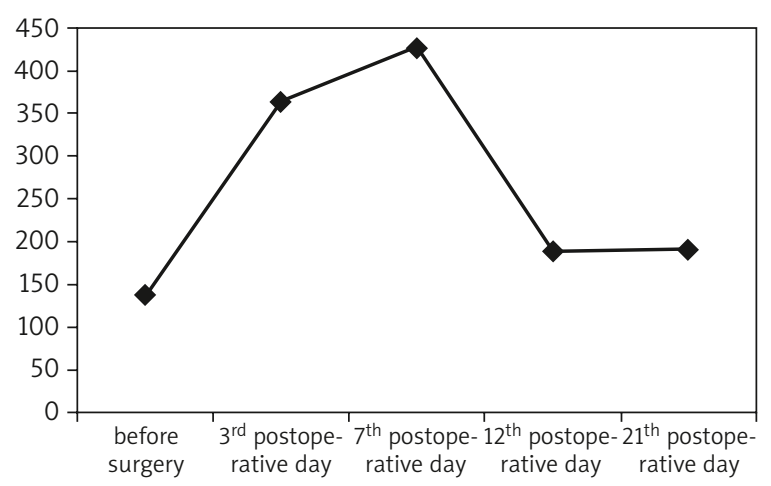

Fig. 1. Changes of Ir at consecutive control points for the group with complications. (description in the text)

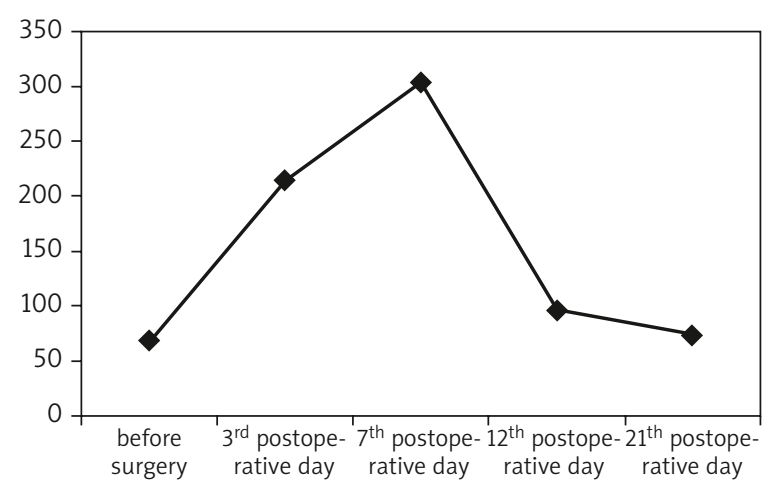

Fig. 3. Changes of Im at successive control points for the group with complications. A lower increase of this parameter than the Ir increase can be seen on the $3^{\text {rd }}$ postoperative day, while on the $21^{\text {st }}$ its decrease is more clear than the one for $\mathrm{Ir}$
Three (10.34\%) patients were operated on in an urgent mode. The perioperative mortality was $10.34 \%$ (3 patients). It concerned 2 patients operated on in an urgent mode and 1 demanding surgery during the same hospitalization. In 2 (6.9\%) patients respiratory insufficiency lasting over $72 \mathrm{~h}$ and demanding prolonged mechanical ventilation and continuation of the treatment in another department occurred. In 2 (6.9\%) patients IABP usage was essential. The average duration of the ICU stay was 3.8 days, while the average hospitalization time was 34.45 days (for group B respectively, 4.3 and 32.64, for group A 3.25 and 36.2; NS, respectively $p=0.13$ and $p=0.28$ ).

\section{Discussion}

The clinical efficacy of the risk indicator (Ir) in the preoperative period is not questionable. However, its reliability in the postoperative period seems to be much more controversial. Cardiosurgical procedures are connected not infrequently with considerable intraoperative blood loss, which imposes transfusion of the blood and blood-derived preparations, disturbing the variability depending on the infective process. Despite this, in our observation the course of morphological parameters was proceeding

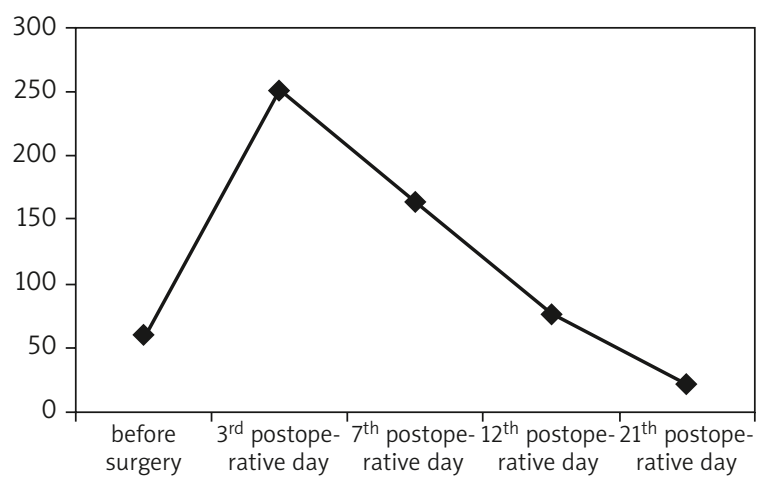

Fig. 2. Changes of Ir at consecutive control points for the group without complications. (description in the text)

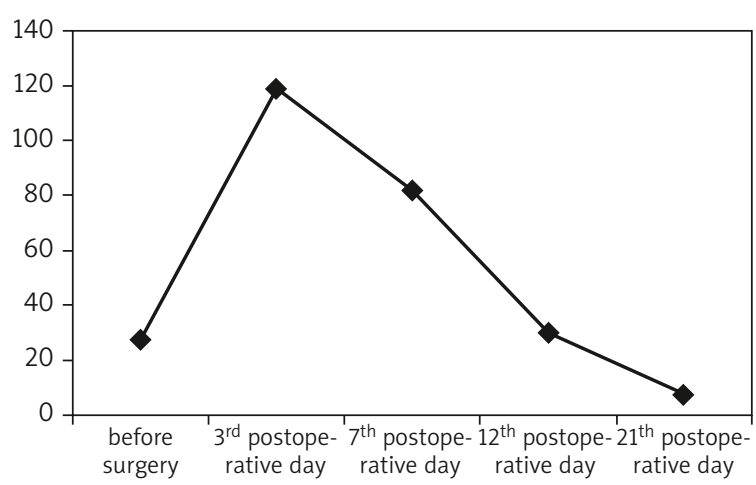

Fig. 4. Changes of Im at successive control points for the group without complications. In the uncomplicated group the Im and Ir curve are compatible 
analogically like CRP (an increase after the operation and significant decrease on the $12^{\text {th }}$ day). However, it must be said that the majority (only 15 PRBC from 78 in total transfused were given in the operating theater during surgery) of blood and blood-derived preparations were transfused already in the postoperative period (mainly in the ICU, that is the first 3-4 days).

$\mathrm{Hb}$ and $\mathrm{RBC}$ are the principal parameters measured in anemia. However, depending on the cause of anemia their alterations proceed distinctly. We decided to check if RBC in prognosis in cardiosurgical patients with IE will significantly impact the indicator's alterations. As it turned out, both parameters Ir ( $\mathrm{Hb}$ ) and Im (RBC) are equivalent. As emphasized in the study by B. Kraśnicka-Sokót et al. [6] for outcome evaluation and as we proved in the above study, for the prediction of postoperative complications, the most important is to confirm low morphological parameters with coexisting high CRP values.

The Ir as well as Im indicator values are linearly proportional to CRP level. However, concerning sudden alterations of this parameter, it seems to influence much more both indicators than the blood morphology does.

The majority of complications appeared in the first postoperative week, when both indicators as well as CRP remained high. The higher preoperative Ir >100 (according to B. Kraśnicka-Sokół's study) was indeed concerned with a higher risk of complications and also, as we confirmed in our study, with a higher risk of postoperative complications. However, as we analyzed the postoperative course in patients with Ir $>100$, it turned out that in 2 (among 8) cases no complications occurred after the surgery. On the other hand, in 11 patients with Ir < 100 complications occurred.

We additionally observed that in operated patients with postoperative complications (despite the CRP decrease) both indicators did not have a lowering tendency after the $3^{\text {rd }}$ day and their values were significantly higher. In our opinion the value $>300$ for $\mathrm{Ir}$ and $>200$ for Im on the $3^{\text {rd }}$ postoperative day can be predictive for the occurrence of complications in the first week following surgery. In the group of patients involved in our study both indicators had important input in monitoring the postoperative treatment, which moreover is well reflected by Figures 1-4.

Our observation can suggest that (Im value in the group with complications) Im > 60 may be predictive for a complicated postoperative course. Both indicators show mutual dependency.

The influential disadvantage of our study is the fact that all kinds of complications were collected together: neurological, circulatory, respiratory and coagulative. We decided to make that simplification due to the small study population. Results of the Nomura A et al. [9] study revealed that one of the complications - heart failure, neurological complications (CNS) or peripheral and central embolism - is an independent risk factor for 90-day mortality.

It must also be underlined that occurrence of major complications depended strongly on the previous patient's characteristics (Table I), which is any way a common fact, repeatedly emphasized by other authors [10]. Prosthetic vaIve endocarditis is a well-known risk factor of postoperative complications [11, 12]. In our observation all 3 patients after redo procedures had complications.

It is worth mentioning that coexisting anemia may be a consequence of comorbidities such as renal insufficiency, which not only leads to anemia, but also hinders blood parameters' normalization. Furthermore, in the group of our patients two had diagnosed deficiency anemia. Ir and Im indicators thereby include the patient's condition as a consequence not only of progression of endocardial infection but also other diseases.

\section{Conclusions}

The prognostic value of Ir indicator for prognosing complications in the postoperative period for patients operated on for IE was proved.

Analogical usefulness for Im indicator was proved and the preoperative value of $I \mathrm{~m}>60$ was estimated as predictive for complicated postoperative course.

Both indicators were useful in monitoring the efficacy of postoperative treatment.

Both indicators, connecting morphological and inflammatory parameters, more properly reflect the patient's clinical condition than the isolated assessment of a singular parameter such as CRP.

\section{References}

1. Bielacz M, Kosek-Hoehne K, Hoehne D, Pawlak S, Janda A. Wpływ chorób przyzębia na rozwój infekcyjnego zapalenia wsierdzia. Kardiochir Torakochir Pol 2011; 8: 394-399.

2. Sokołowska E, Klimek J. Hepcydyna. Hormon uczestniczący w regulacji metabolizmu żelaza w organizmie. Hepcidin. Hormone taking part in the regulation of iron metabolism in the body. Post Biol Kom 2007; 34: 15-30.

3. Hryniewiecki T, Rawczyńska-Englert I, Sitkiewicz D, Jabłoński D. Comparison of interleukin-6 and C-reactive protein serum concentrations assessment in diagnosis of infective endocarditis. Pol Arch Med Wewn 2002; 108: 947-952.

4. Hogevik H, Olaison L, Andersson R, Alestig K. C-Reactive protein is more sensitive than erythrocyte sedimentation rate for diagnosis of infective endocarditis. Infection 1997; 25: 82-85.

5. Widenka K, Mazur W, Stącel T, Kolowca M, Szymanik I, Kurowicki A, Deja M, Woś S. Leczenie chirurgiczne tętniaka rzekomego i ropnia okołozastawkowego w przebiegu bakteryjnego zapalenia wsierdzia. Kardiochir Torakochir Pol 2008; 5: 179-182.

6. Kraśnicka-Sokół B, Kochmański M, Filczak K. Rokownicze znaczenie nowego wskaźnika ryzyka u chorych na infekcyjne zapalenie wsierdzia. Pol Merk Lek 2008; 144: 484-486.

7. Li JS, Sexton DJ, Mick N, Nettles R, Fowler VG Jr, Ryan T, Bashore T, Corey GR. Proposed modifications to the Duke criteria for the diagnosis of infective endocarditis. Clin Infect Dis 2000; 30: 633-638.

8. Ostrowski S, Nowak D, Marcinkiewicz A, Kasielski M, Zwoliński R, Jaszewski R. Ocena skuteczności leczenia chirurgicznego pacjentów z infekcyjnym zapaleniem wsierdzia poprzez obserwację zmian wybranych markerów stanu zapalnego w okresie pooperacyjnym. Assessment of the surgical treatment of patients with infective endocarditis through observation of alterations in selected inflammatory markers in the postoperative period. Kardiochir Torakochir Pol 2011; 8: 183-190.

9. Nomura A, Omata F, Furukawa K. Risk factors of mid-term mortality of patients with infective endocarditis. Eur J Clin Microbiol Infect Dis 2010; 29: 1355-1360.

10. Ostrowski S, Zasłonka J, Jaszewski R, Wojciechowski M, Barylski M, Okoński P, Banach M. Analiza przebiegu okresu pooperacyjnego oraz wczesnych wyników operacyjnego leczenia infekcyjnego zapalenia wsierdzia. Analysis 
The Ir indicator and its modification Im in patients operated on for infective endocarditis...

of postoperative period and early results of surgical treatment of infective endocarditis. Chir Pol 2004; 6: 231-238.

11. Trzeciak P, Poloński L, Zembala M. Infekcyjne zapalenie wsierdzia u chorych ze sztuczną zastawką serca - niedoceniany i groźny problem. Top Medical Trends 2007. Przewodnik Lekarza 2007; 34-37.

12. Grupa Robocza Europejskiego Towarzystwa Kardiologicznego (ESC) do spraw zapobiegania, rozpoznawania i leczenia infekcyjnego zapalenia wsierdzia. Wytyczne dotyczące zapobiegania, rozpoznawania i leczenia infekcyjnego zapalenia wsierdzia. (Nowa wersja- 2009). Kardiol Pol 2010; 68 (supl. 1): 3-52. 